
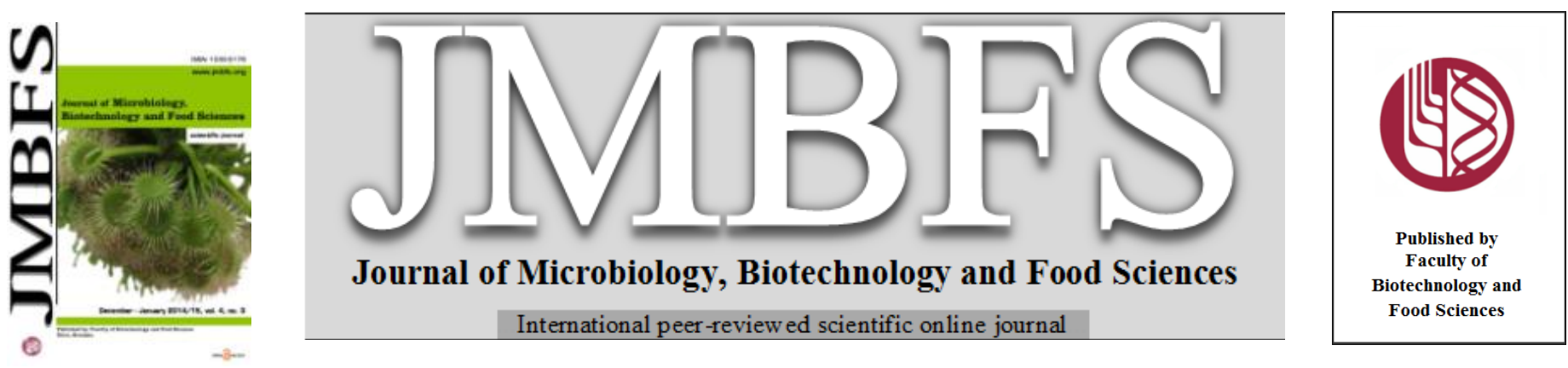

\title{
ESTIMATING THE PREVALENCE OF POLYPHENOLIC COMPOUNDS IN ONIONS (ALLIUM CEPA L.) AND THEIR PRODUCTS
}

\section{Sabina Lachowicz}

Address(es): Sabina Lachowicz

${ }^{1}$ Wroclaw University of Environmental and Life Sciences, The Faculty of Life Sciences, Departament of Fruit, Vegetable and Cereals Technology, Chelmonskiego 37/41 Street, 51-630 Wroclaw, Poland, Phone number: 0048 71-320-77.

*Corresponding author: sabinalachowicz90@gmail.com

doi: 10.15414/jmbfs.2014-15.4.3.213-216

\section{ARTICLE INFO}

Received 26. 8. 2014

Revised 7. 10. 2014

Accepted 13. 10. 2014

Published 1. 12. 2014

Regular article

OPEN $\partial_{\text {ACCESS }}$

\begin{abstract}
Onion is vegetable with good nutrition and its growth could stand different kinds condition. It's medical properties attract researchers attention. The author characterized the preparations and the phenolic compounds from fresh onions (red, yellow, white and shallots) mild pickles in brine and syrup using ultra performance liquid chromatography coupled with mass spectrometer (UPLC-PDA-MS). The results are reasonable and analysis is acceptable. The test material was identified: quercetin, isorhamnetin and derivatives of these compounds. The total content of phenolic compounds in fresh onions ranged from 0.72 to $89.47 \mathrm{mg} .100 \mathrm{~g}^{-1}$ dry weight, mild pickles in brine from 5.39 to $0.31 \mathrm{mg} .100 \mathrm{~g}^{-1}$, syrup from 2.85 to $0.31 \mathrm{mg}^{-1} \mathrm{l}^{-1}$. Polyphenol content was highest in fresh onions, and much lower in the material subjected marinating process.
\end{abstract}

Keywords: Onions (Allium cepa L.), mild pickles, syrup, polyphenols, ultra performance liquid chromatography (UPLC)

\section{INTRODUCTION}

Onion (Allium cepa L.) is a biennial plant, belongs to the lily family, widely distributed in temperate climates (optimal conditions for its development). It shows a number of properties, among others, bactericidal, diuretic, digestive and acting on the heart, eyes and joints. It is characterized by high nutritional value Onion is present in various forms, shapes and flavors. For the Allium family include onions, shallots, green onion, leek, garlic and chives. It is commonly used natural remedy. It occurs in brown, yellow, white, and red-purple. Onion flavor is dependent on the species-from acute after the pleasantly sweet and mild. Each of the bulbs causes irritation of mucous eye and as a result, tearing caused by volatile compounds released during cutting or crushing plants. Onions is a common addition to many dishes are eaten both raw and after being subjected to heat treatment as a seasoning or a separate dish (Bogacz, 2011; Chrobaczek, 1964; Malachowski, 1990).

Onions (Allium cepa L.) is a rich source of vitamins (A, B1, B2, B6, C, PP, K, H) and mineral salts such as sodium, zinc, iron, phosphorus, sulfur, calcium, potassium, iodine, magnesium. It is also a vegetable source of energy and contains about $12.5 \%$ by dry weight, the amount of energy that provides the body can be compared with vegetables, such as sugar beet and carrots. In its composition contains a protein, sugar $(6,3-11,2 \%)$ and fat content about $0.1 \%$ The onions also includes amino acids (cysteine and methionine), sulfides (fitoncida), calcium oxide (about 20\%), malic acid, citric acid, essential oil in an amount of about $0.3-0.5 \%$, where disulphide, trisulphide, n-propyl, and are the main dwumetylotiofen its components. Essential oils occur in all parts of the plant. In contrast, external husk plants are a rich source of flavonoids, especially quercetin and kempferolu. The onions also contains sulfur compounds such as dimethyl sulfoxide propynylocysteiny S-, propyl-, methyl-, propynyloalliinę and mucilages, pectins, and fiber. during cutting onion LFS isolated enzyme reacts with sulfur-containing amino acids and transforms them into sulfonic acids, which pass in a volatile sulfinyl acetate causing watery, irritating the mucosa of the eyes.

Onions due to its health properties. It has antibacterial, antiviral, antiinflammatory. Strengthening effect on the human body and prevents diseases and infections (Babik, 2004; Bogacz, 2011; Chrobaczek, 1964; Kołota, 2007; Piesiewich et al., 2000, Pokorska, 2004; Lonczak, 2009; Bonenberg, 2011; Bruzewicz 2007; Gorinstein et al., 2006).

Onions contains flavonoids including quercetin with antioxidant properties that reduce the risk of developing various forms of cancer and heart disease. Occurrence confirmed her examinations at the University of California at
Berkeley, where it has been shown that quercetin include red onion in the highest quantities, yellow, and shallots. Additionally, included in the red onions powerful antioxidant reduces inflammation that causes allergy during allergy. It also helps in the fight against asthma symptoms (Babik, 2004; Lonczak, 2009).

Onion contains sulfur compounds, which a large amount of variation is present in this vegetable yellow. These studies have shown that sulfur compounds which are in onions, can prevent the biochemical chain reaction that causes a heart attack. Also has anti-cancer properties of selenium. Quercetin with vitamin PP content lowers the harmful cholesterol, causing the deposition of plaques in blood vessels, and increases the amount of cholesterol favorable. Through the above action protects against hypertension, and myocardial infarction. Vegetable affects detoxication and immune your body and lowers blood sugar and calms the nerves (Babik, 2004; Bogacz, 2011; Grzelek, 2006).

Marinades are products made from vegetables, fruits, or mushrooms. They are produced mainly in vinegar, additionally spiced, at the end subjected to a pasteurisation process. For the production of the marinade used is usually fermented vinegar, or one that was created during acetic acid fermentation, with the power to $4-10 \%$. There are mild marinade containing $0.4-0.8 \%$ acetic acid medium containing the marinade $1-1.5 \%$ acetic acid and strong marinade containing up to $3 \%$ acetic acid. The main component of pickle pickled vegetables and fruit is water. Water should possess all the qualities of drinking water. Spices used in pickling onions are: bay leaf, salt, sugar, allspice, mustard seeds, peppercorns (Oszmaiński et al., 2013; Piesiewicz et al., 2000; Małachoński, 1990; Jarczyk et al., 2010).

Onion syrup is produced mostly in the home, at a time when it is needed for colds in order to strengthen the body's resistance and fight against the disease. Syrup with a high percentage of onions owes components contained therein with a germicidal effect (compounds of sulfur, glukokininy, glucosides, pectin), antiinfectives (potassium, iodine) and vitamins (A, B1, B2, C, fitoncida, PP). It has a pungent smell, a sweet-spicy taste and has a mild effect on the body (Oszmaiński et al., 2013; Piesiewicz et al., 2000; Małachoński, 1990; Jarczyk et al., 2010).

This vegetable is also a source of valuable phenolic compounds. Polyphenols are the largest group of natural antioxidants. It has been proven by a number of studies that polyphenols protect the health by preventing oxidative stress and free radical scavenging. In epidemiological studies found a negative correlation between the presence of polyphenols in the body after they are consumed and mortality from heart disease and stroke. Flavonoids belong to the group of polyphenols, characterized by many biological and pharmacological properties to be considered as health promoting. These are mainly anti-cancer, antiinflammatory, antiallergic, anti-viral and anticoagulant effects. Many of the 
properties of healthy flavonoids, result from their antioxidant functions and the capability to modify enzymes, therefore, they are responsible for immunological effects, and carcinogenicity. Many flavonoids prevent diseases of the vascular system, inhibit platelet aggregation and muscle tension surrounding arteries (Bonaccorisi et al., 2008; Horbowicz, 2000; Mitek et al., 2007; Mitek et al. 2010; Oszmiański, 2007; Rosicka-Kaczmarek, 2004; Martincova et al., 2008; Wojcieszyńska et al., 2006).

\section{MATERIAL AND METHODS}

\section{The plant material}

The material consisted of four varieties of red, yellow, white and shallo onions. Both of the yellow and red onions were purchased at the "Lidl" shop in Rzeszow. White onion were purchased at the "Centrum" shop in Rzeszow, shallot onion were purchased at the "Hetman" shop in Rzeszow.

\section{The process of preparing the syrup}

The syrup was prepared from the purified material. Chop onions finely chopped and placed in a pre-prepared individual package - jar. The next step was to backfill material so prepared with sucrose, the closing of packaging and discontinuation in a dark place for 24 hours. After this time squeezed through cheesecloth was placed in the syrup jars and stored under refrigeration at $4{ }^{\circ} \mathrm{C}$ The mass ratio of garlic and onion was $2.3: 1$ sugar (70\%: $30 \%)$

\section{The process of preparing the marinade}

The raw material has been properly cleaned, prepared and placed in jars Each jar also been added: 1 bay leaf, allspice 5 balls, 8 balls granular pepper, $1 / 4$ teaspoon mustard. In contrast, poured consisted of $10 \%$ acetic acid constituting $0.8 \%$ or $8 \mathrm{ml} / 100 \mathrm{ml}$, a salt of a $1 \%$ or $1 \mathrm{~g} / 100 \mathrm{ml}$, constituting $3-4 \%$ of sugar, which $3-4 \mathrm{~g} / 100 \mathrm{ml}$, and water, which was the residue in 31 lagoons. After baking the lagoons has been placed in the jars After tight closure subjected to pasteurization at $85{ }^{\circ} \mathrm{C}$ for $20 \mathrm{~min}$. The final stage in the pickle is cooled at room temperature.

\section{Preparation of samples}

The fresh onions frozen, next all samples were lyophilized for $48 \mathrm{~h}$. The dried powder $(1000 \mathrm{mg})$ was extracted with $70 \% \mathrm{MeOH}$ at $100{ }^{\circ} \mathrm{C}$ at the pressure of $100 \mathrm{bar}$, in an accelerated solvent extractor in 21 minutes. The polyphenolic fraction has been purified from crude extract using Solid Phase Extraction (C18 Sep-Pak) with $40 \% \mathrm{MeOH}$ in $10 \mathrm{ml}$. The resulting solid was again evaporated 'to dryness "in a vacuum evaporator and then dissolved in 2 $\mathrm{ml}$ of a mixture of water and acetonitrile at a ratio of 1:1. After this time, the extract was centrifuged and the clear filtrate was analyzed by UPLC-PDAMS.

\section{UPLC Chromatography}

Qualitative and quantitative analysis were performed using Ultra Performance Liquid Chromatography coupled to mass spectrometer. Phenolic compounds were separated on a $100 \mathrm{~mm}$ i.d., $1.7 \mu \mathrm{m}$ Acquity BEH C-18 column using the linear gradient of acetonitrile and water. The Column temperature was $50{ }^{\circ} \mathrm{C}$. The flow rate of the mobile phase, which was a linear gradient of acetonitrile in water, was $0.35 \mathrm{ml} . \mathrm{min}^{-1}$. The analysis time was $9.5 \mathrm{~min}$, the injections volume was $5 \mu \mathrm{l}$ injections.

\section{Quantitative and qualitative analysis}

Classifying the individual phenolic compounds contained in grapefruit was made based on the characteristic spectra of UV absorption. To identify compounds mass spectra generated by liquid chromatography this is coupled to a mass detector. For quantitative calculations were used experiment SIR (Single Ion Recording) assigned to a particular individual compound was used. The conversion was based on the calibration curves based on peak area of the low concentration of the substance placed on the reference column.

\section{RESULTS AND DISCUSSION}

Phenolic compounds by the presence in their structure of the chromophore group may be labeled or analyzed using UV detection. It is one of the most popular methods for the determination of plant polyphenols. With increased speed, resolution and sensitivity of UPLC chromatography significantly improves performance marked compounds, shortens analysis time, and provides more information than other traditional methods based on spectrophotometric measurement.

The main polyphenolic compounds that have been identified during the analysis are quercetin, isorhamnetin, and derivatives of these compounds. Both in fresh and processed onions qualitative composition of the compounds was the same. The quantitative analysis of polyphenolic compounds was performed using a calibration curve determined for the routine. The ranges of concentrations ranged from 0.222 to $18.75 \mu \mathrm{g} . \mathrm{ml}-1$. The coefficient of determination was 0.999 .

$\underline{\text { Table } 1 \text { Polyphenol content in fresh onions in } \mathrm{mg} \cdot 100 \mathrm{~g}^{-1}}$

\begin{tabular}{lcccc}
\hline Name single reduction & $\begin{array}{c}\text { Yellow } \\
\text { onion }\end{array}$ & $\begin{array}{c}\text { Red } \\
\text { onion }\end{array}$ & $\begin{array}{c}\text { White } \\
\text { onion }\end{array}$ & $\begin{array}{c}\text { Shallot } \\
\text { onion }\end{array}$ \\
\hline $\begin{array}{l}\text { 3,7,4 '-triglucoside } \\
\text { quercetin }\end{array}$ & 0.013 & 0.343 & 0.432 & 0.083 \\
7,4 '-diglukoside quercetin & 0.155 & 27.424 & 35.153 & 4.031 \\
3 glucoside quercetin & 0.394 & 22.947 & 27.468 & 6.814 \\
3-O-rutinoside quercetin & 0.024 & 0.143 & 1.002 & 0.173 \\
3,4 'diglukoside & 0.045 & 0.956 & 2.028 & 0.515 \\
isorhamnetin & 0.043 & 12.002 & 19.345 & 1.281 \\
3 'glucoside quercetin & 0.014 & 0.063 & 0.542 & 0.056 \\
Quercetin ramnoside & 0.071 & 1.068 & 3.501 & 0.696 \\
4'-glucoside isorhamnetin & $\mathbf{0 . 6 4 3}$ & $\mathbf{6 2 . 9 2 2}$ & $\mathbf{8 3 . 9 4 4}$ & $\mathbf{1 2 . 4 3 8}$ \\
\hline Total Quercetin & $\mathbf{0 . 1 1 6}$ & $\mathbf{2 . 0 2 5}$ & $\mathbf{5 . 5 2 9}$ & $\mathbf{1 . 2 1 1}$ \\
Total Isorhamnetin & $\mathbf{0 . 7 6 0}$ & $\mathbf{6 4 . 9 4 7}$ & $\mathbf{8 9 . 4 7 2}$ & $\mathbf{1 3 . 6 4 9}$ \\
Total Polyphenols & & & & \\
\hline
\end{tabular}

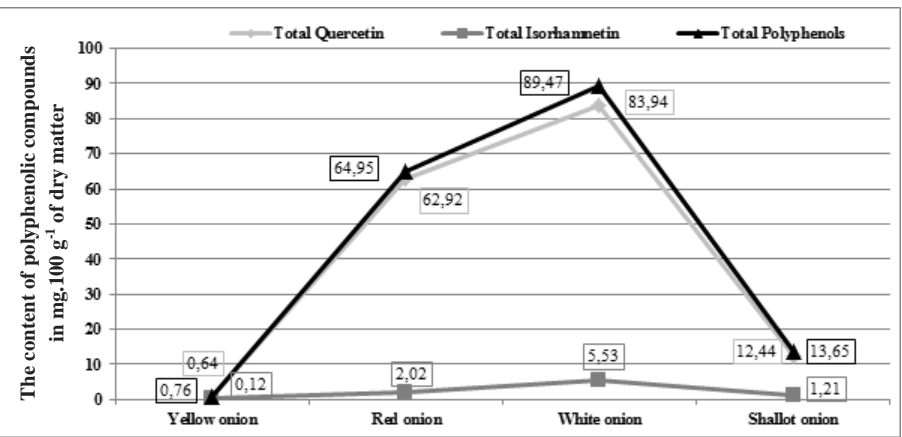

Figure 1 Graphical representation of the content of quercetin, isorhamnetin and their sum in fresh onions

Figure 1 shows the contents of compounds quercetini and isorhamnetin, and total polyphenols for the tested fresh onions: yellow, red, white, shallot. The highest amount of quercetin and isorhamnetin performed in white and red onions, for which these values were, respectively, $83.94 \mathrm{mg} 100 \mathrm{~g}^{-1}, 5.53 \mathrm{mg} .100 \mathrm{~g}^{-1}$ and $62.92 \mathrm{mg} .100 \mathrm{~g}^{-1}, 2.02 \mathrm{mg} .100 \mathrm{~g}^{-1}$. The lowest amount of these compounds was a yellow onions for which amounted to $0.64 \mathrm{mg} .100 \mathrm{~g}^{-1}$ and $0.12 \mathrm{mg} .100 \mathrm{~g}^{-1}$ [Tabele $1]$.

$\underline{\text { Table } 2 \text { Polyphenol content of the pickled onions in } \mathrm{mg} .100 \mathrm{~g}^{-1}}$

\begin{tabular}{lllll}
\hline Name single reduction & $\begin{array}{c}\text { Yellow } \\
\text { onion }\end{array}$ & $\begin{array}{c}\text { Red } \\
\text { onion }\end{array}$ & $\begin{array}{c}\text { White } \\
\text { onion }\end{array}$ & $\begin{array}{c}\text { Shallot } \\
\text { onion }\end{array}$ \\
\hline $\mathbf{3 , 7 , 4}$ '-triglucoside quercetin & 0.003 & 0.011 & 0.002 & 0.004 \\
$\mathbf{7 , 4}$ '-diglukozyd quercetin & 0.199 & 0.877 & 0.045 & 0.324 \\
3 glucoside quercetin & 0.228 & 0.798 & 0.057 & 0.355 \\
3-O-rutinoside quercetin & 0.006 & 0.007 & 0.003 & 0.013 \\
3,4 'diglukozyd & 0.053 & 0.113 & 0.027 & 0.123 \\
isorhamnetin & 0.100 & 0.936 & 0.135 & 0.775 \\
3 'glucoside quercetin & 0.003 & 0.006 & 0.007 & 0.025 \\
4'-glucoside, isorhamnetin & 0.023 & 0.107 & 0.029 & 0.145 \\
\hline Total Quercetin & $\mathbf{0 . 5 3 9}$ & $\mathbf{2 . 6 3 5}$ & $\mathbf{0 . 0 2 0}$ & $\mathbf{1 . 7 8 7}$ \\
Total Isorhamnetin & $\mathbf{0 . 0 7 6}$ & $\mathbf{0 . 2 2 0}$ & $\mathbf{0 . 0 5 6}$ & $\mathbf{0 . 2 6 9}$ \\
Total Polyphenols & $\mathbf{0 . 6 1 5}$ & $\mathbf{2 . 8 5 4}$ & $\mathbf{0 . 3 0 6}$ & $\mathbf{2 . 0 5 6}$ \\
\hline
\end{tabular}




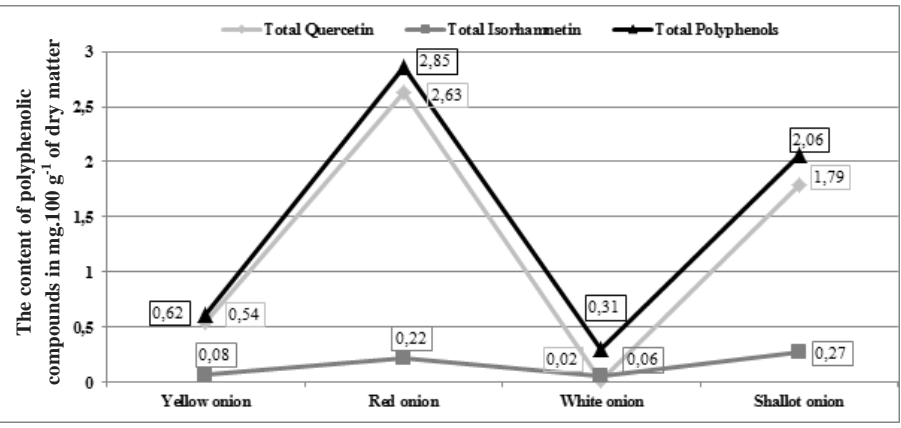

Figure 2 Graphical representation of the content of quercetin, isorhamnetin and their sum in pickled onions

Figure 2 shows the contents of the individual compounds kwercetyni and isorhamnetin, and total polyphenols in the syrup with onions. The highest amount of quercetin and isorhamnetin occurs in syrup with red onions and amounts to $2.63 \mathrm{mg} .100 \mathrm{~g}^{-1}$ and $0.22 \mathrm{mg} .100 \mathrm{~g}^{-1}$. Much less of these compounds are in syrup with onions shallots and amounts to $1.79 \mathrm{mg} 100 \mathrm{~g}^{-1}$ and $0.27 \mathrm{mg} \cdot 100 \mathrm{~g}^{-1}$. The lowest content of quercetin, and isorhamnetin was white onion syrup and was

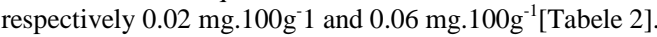

Table 3 Polyphenol content in syrups with onions in $\mathrm{mg} .100 \mathrm{~g}^{-1}$

\begin{tabular}{lllll}
\hline Name single reduction & $\begin{array}{c}\text { Yellow } \\
\text { onion }\end{array}$ & $\begin{array}{c}\text { Red } \\
\text { onion }\end{array}$ & $\begin{array}{c}\text { White } \\
\text { onion }\end{array}$ & $\begin{array}{c}\text { Shallot } \\
\text { onion }\end{array}$ \\
\hline 3,7,4 '-triglucoside quercetin & 0.010 & 0.020 & 0.010 & 0.010 \\
7,4 '-diglukozyd quercetin & 0.020 & 0.805 & 0.042 & 0.080 \\
3 glucoside quercetin & 0.098 & 1.968 & 0.090 & 0.198 \\
3-O-rutinoside quercetin & 0.013 & 0.031 & 0.011 & 0.014 \\
3,4 'diglukozyd & 0.057 & 0.235 & 0.048 & 0.116 \\
isorhamnetin & 1.011 & 1.968 & 0.467 & 1.401 \\
quercetin ramnozyd & 0.077 & 0.098 & 0.057 & 0.077 \\
4'-glucoside, isorhamnetin & 0.396 & 0.270 & 0.172 & 0.417 \\
\hline Total Quercetin & $\mathbf{1 . 2 2 8}$ & $\mathbf{4 . 8 9 0}$ & $\mathbf{0 . 7 7 2}$ & $\mathbf{1 . 7 8 0}$ \\
Total Isorhamnetin & $\mathbf{0 . 4 5 2}$ & $\mathbf{0 . 5 0 4}$ & $\mathbf{0 . 2 1 9}$ & $\mathbf{0 . 5 3 3}$ \\
Total Polyphenols & $\mathbf{1 . 6 8 0}$ & $\mathbf{5 . 3 9 4}$ & $\mathbf{0 . 9 9 2}$ & $\mathbf{2 . 3 1 3}$ \\
\hline
\end{tabular}

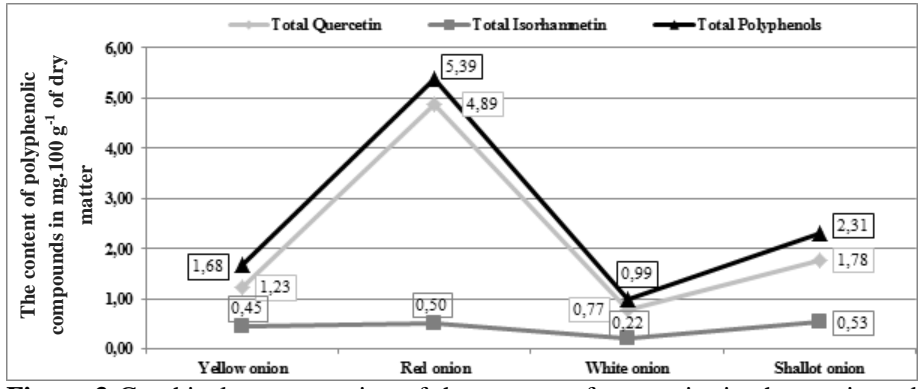

Figure 3 Graphical representation of the content of quercetin, isorhamnetin and their sum in syrups with onions

Figure 3 shows the contents of the individual compounds kwercetyni and isorhamnetin, and total polyphenols in the marinade mild richest in content of quercetin and isorhamnetin was red onion and amounted to $4.89 \mathrm{mg} .100 \mathrm{~g}^{-1}$ and $0.5 \mathrm{mg} .100 \mathrm{~g}^{-1}$. Much less of these compounds were onions shallots and amounts to $1.78 \mathrm{mg} .100 \mathrm{~g}^{-1}$ and $0.53 \mathrm{mg} .100 \mathrm{~g}^{-1}$. Poorest in these compounds was white onion and amounted to 0.77 and $0.22 \mathrm{mg}^{1} 100 \mathrm{~g}^{-1}$ [Tabele 3].

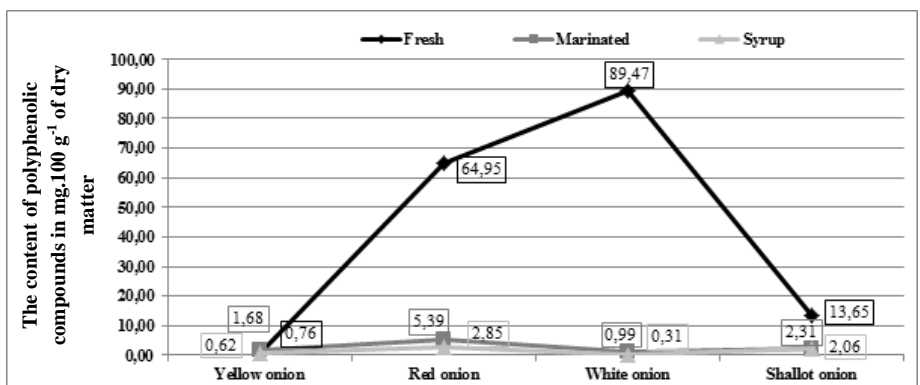

Figure 4 Graphical comparison of the content of polyphenols in fresh onions, pickled onions and syrups based thereon
Figure 4 shows a comparison of the content of phenolic compounds in the dry weight of bulbs tested in subjects pickled onions marinated in mild and syrup. The final content of the compound is shown as the dry matter content $(\mathrm{mg} .100 \mathrm{~g}$ ${ }^{1}$ ). The fresh vegetables are far more polyphenols than the syrups and marinades The polyphenol content of the fresh bulbs ranged from 0.76 to $89.48 \mathrm{mg}^{-100 \mathrm{~g}^{-1}}$ dry weight, and ranged marinades this content from 0.99 to $5.39 \mathrm{mg} .100 \mathrm{~g}^{-1}$ dry

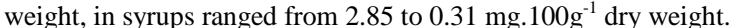

According to a study P. Banaccorsi, C. Caristie, C. Gargiulli, U. Leuzzi content of quercetin in red variety of onion was $64.53 \mathrm{mg}^{100 \mathrm{~g}^{-1}}$ and isorhamnetin was $6.86 \mathrm{mg} .100 \mathrm{~g}^{-1}$ dry weight (Banaccorsi et al., 2008; Drozd et al., 2007). These values are similar to that of the red onions in which these values were 62.92 and $2.02 \mathrm{mg} .100 \mathrm{~g}^{-1}$ dry weight. In the case of yellow onions compounds derived data values are much lower compared to the presented research results and amounted to $0.64 \mathrm{mg} .100 \mathrm{~g}^{-1}$ for quercetin and $0.12 \mathrm{mg} .100 \mathrm{~g}^{-1}$ for isorhamnetin. The values given by these authors were respectively $64.32 \mathrm{mg} .100 \mathrm{~g}^{-1}, 4.54 \mathrm{mg} .100 \mathrm{~g}^{-1}$. These values were very close to the examined white onion garlic. The content of quercetin was $0.66 \mathrm{mg} .100 \mathrm{~g}^{-1}$ and $0.06 \mathrm{mg} .100 \mathrm{~g}^{-1}$ isorhamnetin. In samples of onions shallots from France these authors obtained $114.4 \mathrm{mg} .100 \mathrm{~g}^{-1}$ and 9.3 $\mathrm{mg} .100 \mathrm{~g}^{-1}$ of quercetin isorhamnetin. At the same material originating from Italy contents of the aforementioned compounds were lower and amounted to 104.27 $\mathrm{mg} .100 \mathrm{~g}^{-1}, 4.5 \mathrm{mg} .100 \mathrm{~g}^{-1}$. Comparing these values to the results obtained in the work they are much lower and amounted to $12.44 \mathrm{mg} .100 \mathrm{~g}^{-1}$ of quercetin, isorhamnetin $1.21 \mathrm{mg} .100 \mathrm{~g}^{-1}$.

\section{CONCLUSION}

Onion (Allium cepa L.) is a valuable source of phenolic compounds, mainly quercetin and isorhamnetin. The use of high pressure extraction apparatus for parallel extraction allowed to obtain concentrated extracts in a short time, and lower the temperature of the extraction, thus limiting the loss of heat-labile components. UPLC chromatography allowed for the rapid and accurate analysis of the results. The total content of phenolic compounds in yellow onion was 1.68 mg. $100 \mathrm{~g}^{-1}$ in in onions marinated in a mild brine was $0.76 \mathrm{mg} .100 \mathrm{~g}^{-1}$, while in syrup with onions $0.62 \mathrm{mg} \cdot 1^{-1}$. The total content of phenolic compounds in red onion was $64.95 \mathrm{mg} .100 \mathrm{~g}^{-1}$ in in onions marinated in a mild brine was 5.39 $\mathrm{mg} .100 \mathrm{~g}^{-1}$, while in syrup with onions $2.85 \mathrm{mg} . \mathrm{l}^{-1}$. The total content of phenolic compounds in white onion was $89.47 \mathrm{mg}^{-100 \mathrm{~g}^{-1}}$ in onions marinated in a mild brine was $0.31 \mathrm{mg} .100 \mathrm{~g}^{-1}$, while in syrup with onions $0.31 \mathrm{mg} . \mathrm{l}^{-1}$.

The total content of phenolic compounds in shallots onion was $13.65 \mathrm{mg} .100 \mathrm{~g}^{-1}$

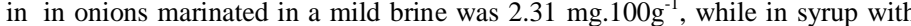
onions $2.1 \mathrm{mg} . \mathrm{l}^{-1}$.The total polyphenol content was highest in fresh onions, and significantly lower in the samples subjected to the process of pickling.

\section{REFERENCES}

BABIK J. 2004. Ekologiczne metody uprawy Cebuli. Materiały dla rolników Radom, 06.

BOGACZ K. 2011. AKB Colsunting. Cebula- „trufla ” nie tylko dla ubogich. Przemyst fermentacyjny i owocowo-warzywny. 3. 37.

BONENBERG K. 2011. Antybiotyk starożytnych. Aura. 1. 34-35.

BONACCORISI P., CARISTI C., GARGIULLI C., LEUZZI U. 2008. Flavono glucosides in Allium species: A comparative study by means

of HPLC-DAD-ESI-MS-MS. Food Chemistry 107. 1668-1673. http://dx.doi.org/10.1016/j.foodchem.2007.09.053

BRUŻEWICZ SZ., MALICKI A. 2007. Stan mikrobiologiczny wybranych przypraw i przeżywalność w nich drobnoustrojów. ŻYWNOŚĆ. Nauka. Technologia. Jakość. 4 (53). 99 - 108.

CHROBACZEK E. 1964. Cebula. Państwowe Wydawnictwo Rolnicze i Leśne. Warszawa, 5-7, 27-38

DROZD M., THOMAS M., NOWAK R. 2011. Determination of phenolic acids raw garlic (Allium sativum L.) and onion (Allium cepa L.) bulbs. Current Issues in Pharmacy and Medical Sciences. Annales Universitatis Mariae CurieSkłodowska. Lublin-Polonia. 1 (14). 121 - 127.

GORINSTEIN A., LEONTOWICZ H., LEONTOWICZ m., NAMIESNIAK J. NAJMAN K., DRZEWIECKI J., CVIKROVA M.,

LANZOTTI V. 2006. The analysis of onion and garlic. Journal of Chromatography A. 1112. 3 - 22. http://dx.doi.org/10.1016/j.chroma.2005.12.016 MARTINCOVA O., KATRICH E., TRAKHTENBERG S. 2008. Comparison of the Marin Bioactive Compounds and Antioxidant Activities in Garlic and white and red onions after treatment protocols. Journal of Agricultural and Food Chemistry. 56. 4418 - 4426. http://dx.doi.org/10.1021/jf800038h

GRZELEK K. 2006. Cebula jako źródło prebiotyków w okresie jesienno zimowym. ŻYWNOŚĆ. Nauka. Technologia. Jakość. 2 (47). $67-75$.

HORBOWICZ M. 2000. Kwercetyna i jej występowanie. Przegląd Piekarski Cukierniczy. 04. 16-17.

JARCZYK A., PŁOCHARSKI W. 2010. Technologia Produktów owocowych i warzywnych. Wyższa szkoła ekonomiczno-humanistyczna im. 215rof.. Sz. A Pieniażka w Skierniewicach. 2. 149 - 177.

KOŁOTA E., ORŁOWSKI M., BIESIADA A. 2007. Warzywnictwo. Wydawnictwo Uniwersytetu Przyrodniczego we Wrocławiu. Wrocław. 303-305. 
LONCZAK A. 2009. Cebula- warzywo pełne zalet. Zdrowa Żywność, Zdrowy Styl Życia.1/83. 14-15.

MAŁACHOWSKI A. 1990. Warzywa cebulowe. Państwowe Wydawnictwo Rolnicze i Leśne. 157-160.

MITEK M., GASIK A. 2007. Polifenole w żywności. Właściwości przeciwutleniające. Przemyst Spożywczy. 9. 36-39, 44.

MITEK M., GASIK A. 2010. Polifenole w żywności. Wpływ na cechy organoleptyczne żywności. Przemyst spożywczy. 64. 10. 46.

OSZMIAŃSKI J. 2007. Prozdrowotne polifenole w chorobach serca i naczyń krwionośnych. Przemyst Fermentacyjny i Owocowo-Warzywny. 7-8. 42-43.

OSZMIAŃSKI J., KOLNIAK-OSTEK J., WOJDYŁO A. 2013. Characterization and Content of Flavonol Derivatives of Allium ursinum L. Plant. Journal of Agricultural and Food Chemistry. 61. 176-184 http://dx.doi.org/10.1021/jf304268e

PIESIEWICZ H., WASILUK M. 2000. Cebula - wartość odżywcza, właściwości lecznicze i zastosowanie w piekarnictwie. Przegląd Piekarski i Cukierniczy. 04 $12-15$.

POKORSKA B. 2004. Król przypraw. Przegląd gastronomiczny. 3. 62-63.

ROSICKA-KACZMAREK J. 2004. Polifenole jako naturalne antyoksydanty w żywności. Przeglad Piekarski i Cukierniczy. 6. 12-16.

WOJCIESZYŃSKA D., WILCZEK A. 2006. Związki fenolowe pochodzenia naturalnego. Nauka i Technika.6-12. 